\title{
ADAPTABILITY AND PRODUCTIVE STABILITY OF SOYBEAN GENOTYPES UNDER NATURAL RUST INFECTION WITHOUT FUNGICIDE
}

\author{
ADAPTABILIDADE E ESTABILIDADE PRODUTIVA DE GENÓTIPOS DE SOJA \\ SOB INFECÇÃO NATURAL POR FERRUGEM, SEM FUNGICIDA
}

\author{
Nathália Salgado SILVA ${ }^{1}$; Ana Paula Oliveira NOGUEIRA²; \\ Osvaldo Toshiyuki HAMAWAKI ${ }^{3}$; Fábio Serafim MARQUES ${ }^{4}$; Luíza Amaral MEDEIROS ${ }^{5}$; \\ Géssyca Ferreira GOMES ${ }^{5}$; Bianca Gonçalves GUIMARÃES ${ }^{6}$; Lucas Oliveira Araújo PENA ${ }^{7}$; \\ Cristiane Divina Lemes HAMAWAKI ${ }^{8}$; Fernando Cezar JULIATTI ${ }^{3}$ \\ 1. Doutoranda em Genética e Melhoramento de Plantas na Escola Superior de Agricultura "Luiz de Queiroz", Piracicaba, SP, \\ Brasil.nathalia_salgadosilva@yahoo.com.br; 2. Professora do Instituto de Biotecnologia, Universidade Federal de Uberlândia, \\ Uberlândia, MG, Brasil; 3. Professores Titulares do Instituto de Ciências Agrárias na Universidade Federal de Uberlândia, \\ Uberlândia, MG, Brasil; 4. Mestrando em Fitotecnia na Universidade Federal de Lavras, Lavras, MG, Brasil; 5. Estudantes de \\ Biotecnologia na Universidade Federal de Uberlândia, Uberlândia, MG, Brasil; 6. Estudante de Agronomia na Universidade \\ Federal de Uberlândia, Uberlândia, MG, Brasil; 7. Biólogo formado na Universidade Federal de Uberlândia, Uberlândia, MG, \\ Brasil; 8. Doutoranda em Agronomia na Universidade Federal de Uberlândia, Uberlândia, MG, Brasil.
}

\begin{abstract}
The genetic breeding of soybean aims to obtain productive genotypes, so it is necessary that the genetic components, environment and the interaction between them be understood. The $\mathrm{G} \times \mathrm{E}$ interaction is the differential behavior of the genotypes against environmental. The objective was to study the $\mathrm{G} \times \mathrm{E}$ interaction and analyze the adaptability and stability of soybean genotypes under natural rust infection without fungicide. The experiment was conducted in the Genetic Breeding Program of the Federal University of Uberlândia. Fourteen soybean genotypes were evaluated, with 10 lines developed by the UFU Program (UFUS1117: 01, 02, 03, 05, 06, 07, 08, 09, 10 and 11) and 4 cultivars: UFUS 7415, UFUS Riqueza, TMG 801 and BRSGO 7560 in four seasons: 2013/14, 2014/15, 2015/16 and $2016 / 17$, in a randomized complete block design. The G x E interaction was complex and the $\mathrm{H}^{2}$ was $85.97 \%$ indicating superiority of genetic variation in relation to the environment. The average grain yield was $2284.13 \mathrm{~kg} \mathrm{ha}^{-1}$. The genotype UFUS 1117-01 was identified by Eberhart and Russel, Wricke, AMMI 2 and Centroid as being a highly productive stability genotype. The UFUS 1117-07 showed high stability by Eberhart and Russel, Wricke, Lin and Binns modified by Carneiro methods and wide adaptability by Eberhart and Russel and Centroid. The genotype UFUS 1117-09 was identified as being adaptable to unfavorable environments by the Lin and Binns modified by Carneiro and Centroid methods, and UFUS 1117-10 presented favorable environmental adaptability by the Centroid method and high stability by Eberhart and Russel.
\end{abstract}

KEYWORDS: Glycine max. G x E interaction. Cultivar recommendation. Biometric analysis.

\section{INTRODUCTION}

Variations in soybean yield grain occur not only as a function of cultivar and environmental conditions but also of genotype interaction by environments (SEDIYAMA; SILVA; BORÉM, 2015). The genotype interaction by environments ( $\mathrm{G} \times \mathrm{E}$ ) is characterized as the differential behavior of genotypes due to environmental variations (CRUZ; CARNEIRO; REGAZZI, 2014), hinders the evaluation of productive potential and the selection of superior materials, inflates estimates of genetic variance resulting in overestimation of the expected gains with selection and in less successful breeding programs (DUARTE; VENCOVSKY, 1999). A interaction has fundamental importance in the phenotypic manifestation, because it reflects the sensitivity differences of the genotypes towards environmental variations, resulting in changes in the behavior of the materials (RAMALHO et al., 2012), and should, therefore, be estimated and considered in the genetic improvement and indication of cultivars.

Due to the inconsistency of genotype superiority in environments, the use of specific cultivars for each environment or with high adaptability and high stability has been recommended (GARBUGLIO; FERREIRA, 2015). Adaptability is comprehended as the ability of the genotype to benefit from environmental variations, while stability reflects is the ability of genotypes to show a highly predictable behavior in data environmental stimuli (CRUZ; CARNEIRO; REGAZZI, 2014).

From the studies of adaptability and stability, it is possible to infer about the productive characteristics of the genotypes to recommend the appropriate cultivars to different regions of cultivation, allowing to the farmer a greater profitability. In this way, it is possible to obtain more productive cultivars with desirable agronomic characteristics, consistently superior and responsive to environmental variations, which are the main objectives of a breeding program of any economic species. 
The objective was to evaluate the productive performance of soybean lines and cultivars in four seasons in the city of Uberlândia, MG and to determine the adaptability and productive stability by parametric, non-parametric and multivariate methods of soybean genotypes under natural rust infection without fungicide.

\section{MATERIAL AND METHODS}

The experiments were conducted in the 2013/14, 2014/15, 2015/16 and 2016/17 crop seasons at Capim Branco farm, in Uberlândia, belonging to the Federal University of Uberlândia. Fourteen soybean genotypes were evaluated, of which 10 were developed by the UFU Soybean Breeding Program (UFUS 1117-01, UFUS 1117-02, UFUS 1117-03, UFUS 1117-05, UFUS 1117-06, UFUS 1117-07, UFUS 1117-08, UFUS 1117-09, UFUS $1117-10$ and UFUS 1117-11) and 4 cultivars (UFUS 7415, UFUS Riqueza, TMG 801 and BRSGO 7560).

The experiments were conducted in a randomized complete block design with three replicates. Each plot consisted of four rows of soybean plants, $5.0 \mathrm{~m}$ in length with spacing between rows of $0.5 \mathrm{~m}$, totaling $10.0 \mathrm{~m}^{2}$. The useful area was the two central lines of each plot, being eliminated $0.50 \mathrm{~m}$ from each end, referring to the border, totaling $4.0 \mathrm{~m}^{2}$.

The soil was prepared conventionally, with a plowing and two harrowing. Before sowing, the area was furrowed and fertilized with the formulation $02-28-18$ at the dose of $400 \mathrm{~kg} \mathrm{ha}^{-1}$. The seeds were treated with the fungicide composed of Carbendazim and Tiram and then inoculated with Bradyrhizobium japonicum.

The sowing occurred on 12/12/2013, $11 / 29 / 2014,02 / 12 / 2015$ and $11 / 5 / 2016$, in a depth of 3 to $5 \mathrm{~cm}$. Soon after sowing, the herbicides of active principles S-Metolachlor and Haloxyfop-PMethyl were applied. The thinning was performed maintaining 15 seeds per linear meter. Manual weeding was performed during the cycle to maintain the culture clean.

Thirty days after emerging, foliar fertilizer composed of Cobalt and Molybdenum at a dose of $100 \mathrm{~mL} \mathrm{ha}^{-1}$ was applied and pest control was performed with Acefate at the dose of $0.4 \mathrm{~kg} \mathrm{ha}^{-1}$ and insecticide composed of Tiametoxam and Lambda- Cyhalothrin at a dose of $200 \mathrm{~mL} \mathrm{ha}^{-1}$.

Grain yield was determined by harvesting the useful area of each plot followed by grain weighing. We proceeded with the analysis of joint variance with 14 genotypes in 4 environments, in which the effects of genotypes and environment were considered fixed. The statistical analyzes were performed in the Genes Program (CRUZ, 2016).

A study of the $\mathrm{G} \times \mathrm{E}$ interaction was carried out from the decomposition in a complex part between environment pairs, as described by Cruz and Castoldi (1991). Thus, the complex part was obtained by the expression: $\mathrm{C}=(1-r)^{3} \sqrt{\mathrm{Q}_{1} \mathrm{Q}_{2}}$ where: Q1 and Q2: correspond to the average squares of genotypes in environments 1 and 2 respectively; r: correlation between the means of the genotypes in the two environments.

The experimental precision was evaluated by the coefficient of variation $(\mathrm{CV} \%)$ and then the genotype determination coefficient was determined $\left(\mathrm{H}^{2}\right)$. Once the significant $\mathrm{G} \times \mathrm{E}$ interaction was detected, adaptability and productive stability were analyzed by the methods of Eberhart and Russel (1966): $\hat{\beta}=\frac{\Sigma_{j} y_{i j} I_{j}}{\Sigma_{j} I_{j}^{2}}$ e $\hat{\sigma}_{\mathrm{di}}^{2}=\frac{\mathrm{QMD}_{\mathrm{i}}-\mathrm{QMR}}{\mathbf{r}}$, where $\mathrm{QMD}_{\mathrm{i}}$ is the mean square of the deviations of genotype $\mathrm{i}$; QMR: is the mean square of the residue; $\mathrm{r}$ : is the number of repetitions; Wricke (1965): $\omega_{\mathrm{i}}=\Sigma\left(\mathrm{Y}_{\mathrm{ij}}-\overline{\mathrm{Y}}_{\mathrm{i} .}-\overline{\mathrm{Y}}_{\mathrm{j}}+\mathrm{Y}\right)^{2}$, where Yij: mean of genotype $\mathrm{i}$ in the environment $\mathrm{j} ; \overline{\mathrm{Y}_{\mathrm{i}}}$ mean of genotype $\mathrm{i} ; \overline{\mathrm{Y}_{\mathrm{j}}}$ : environment average $\mathrm{j}$; $\overline{\mathrm{Y} . .}$ : overall mean; Lin and Binns (1988) modified by Carneiro (1998): $P_{i}=\frac{\sum_{j=1}^{n}\left(X_{i j}-M_{j}\right)^{2}}{2 n}$ where Pi is the estimate of the stability parameter of the i-th genotype, Yij: is the productivity of the $\mathrm{i}$-th genotype in the $\mathrm{jth}$ environment; $\mathrm{Mj}$ : is the maximum observed response among all genotypes in the jth environment; $\mathrm{n}$ : is the number of environments. Centroid (ROCHA et al., 2005): $I_{j}=\frac{1}{g} \sum_{i} Y_{i j}=\frac{1}{a g} Y$ where $Y_{i j}$ : mean of genotype $\mathrm{i}$ in environment $\mathrm{j} ; \mathrm{Y}$ : total of observations; a: number of environments; $\mathrm{g}$ : number of genotypes. AMMI 2 (ZOBEL et al., 1988):

$\overline{Y_{i j}}=\mu+g_{i}+a_{j}+\sum_{c=1}^{q} \sqrt{\lambda_{c}} \alpha_{i c} \gamma_{j c}+\delta_{i j}+\bar{e}_{i j}$ where: $Y_{i j}$ : mean observed for the response variable of genotype $\mathrm{i}$ in environment $\mathrm{j} ; \mu$ : overall mean; $g_{i}$ : effect of genotype $\mathrm{i}, \mathrm{i}=1,2,3 \ldots, \mathrm{g} ; \boldsymbol{a}_{j}$ : effect of the environment $\mathrm{j}, \mathrm{j}=1,2,3 \ldots, \mathrm{a} ; \lambda_{c}:$ : eigenvalue of the c-major main component related to the $\mathrm{G} \times \mathrm{E}$ interaction; $\alpha_{i c}$ : eigenvalue of the c-th major component related to genotype $i ; \gamma_{j c}$ : eigenvalue of the c-th major component related to the environment $\mathrm{j} ; \delta_{i j}$ : residue or noise not explained by the main components; and $\bar{e}_{i j}$ : mean experimental error. 


\section{RESULTS AND DISCUSSION}

The analysis of variance was performed as it was found homogeneity of the variances from the ratio between the largest and the smallest mean square, 4.81 (Table 1), a value lower than seven which is the limit (RAMALHO et al., 2012 ). The coefficient of variation (CV \%) was estimated at $21.26 \%$ (Table 1), which is acceptable since productivity is quantitative and highly influenced by the environment (LEITE et al., 2015).

Significance was verified by the $\mathrm{F}$ test $(\mathrm{P}$ $<0.01$ ), for the effects of genotypes, environments and $\mathrm{G} \times \mathrm{E}$ interaction (Table 1). The interaction $\mathrm{G} \times$ $E$ reflects on significant changes in the behavior of the genotypes when submitted to environmental differences and are frequently reported in different autogamous cultures (RAMALHO et al., 2012) as soybean, and it appears due to the different responses of the same set in different environments (COCKERHAM, 1963).

The heritability $\left(\mathrm{H}^{2}\right)$ is a genetic parameter of great importance for the breeding, however, in advanced generations, in which the genotypes present high homozygosity, it is called the genotypic determination coefficient (VASCONCELOS et al., 2012; YOKOMIZO; VELLO, 2000).

The parameter $\mathrm{H}^{2}$ provides information of the proportion of phenotypic variability that is attributed to genetic causes (RAMALHO et al., 2012), thereby measuring the reliability of phenotypic value as an indicator of genotypic value. The estimate of $\mathrm{H}^{2}$ for the productivity trait was $85.97 \%$ (Table 1), being of high magnitude (CRUZ; CARNEIRO; REGAZZI, 2014) and indicating that the genetic variation was superior to environmental.

Table 1. Summary of the joint variance analysis for grain yield $\left(\mathrm{kg} \mathrm{ha}^{-1}\right)$ evaluated in 14 soybean genotypes grown in 4 seasons, in Uberlândia-MG.

\begin{tabular}{ccc}
\hline Sources of Variation & Degrees of Freedom & Medium Square \\
\hline Blocks / Environment & 8 & 646959.64 \\
Genotypes (G) & 13 & $1681942.95^{* *}$ \\
Environments (E) & 3 & $10964484.27^{* *}$ \\
G x E interaction & 39 & $513957.88^{* *}$ \\
Error & 104 & 235944.99 \\
\hline Average & & 2284.13 \\
CV (\%) & 21.26 \\
$\mathrm{H}^{2}$ & 85.97 \\
Relation $>$ QME/<QME & & 4.81 \\
\hline
\end{tabular}

The nature of the $\mathrm{G} \times \mathrm{E}$ interaction was estimated by the method of Cruz and Castoldi (1991), in which it was possible to identify complex type interaction in all pairs of environments. The interaction of the complex type denotes an inconsistency in the superiority of the genotype with the environmental variation, which hinders the process of improvement in the indication of the materials (BORÉM; MIRANDA, 2013), in addition, the interaction between the two species is associated with a lack of genetic correlation between the genotypes.

Through the environmental index of Finlay and Wilkinson (1963), it was possible to identify favorable environments (2013/14 and 2015/16) and unfavorable ones (2014/15 and 2016/17). Favorable environments are those where the influence of abiotic and biotic factors was not able to drastically reduce productivity when compared to unfavorable environments.

In the 2013/14 crop, the averages ranged from $1820 \mathrm{~kg} \mathrm{ha}^{-1}$ to UFUS $1117-02$, to $3645.6 \mathrm{~kg}$ ha $^{-1}$ to TMG 801 (Table 2). A group with 5 genotypes was formed, which had higher yields, 3 of them coming from the UFU Program: UFUS 7415, UFUS 1117-05 and UFUS 1117-07. These genotypes had productivity above the national average (season 2013/14), which was $2854 \mathrm{~kg} \mathrm{ha}^{-1}$ (CONAB, 2017).

In Table 2 it was possible to observe that in relation to the 2014/15 crop, the averages ranged from $1126.42 \mathrm{~kg} \mathrm{ha}^{-1}$ for UFUS Riqueza, to $2088.943 \mathrm{~kg} \mathrm{ha}^{-1}$ for UFUS 1117-08. Among the most productive genotypes, the UFUS 7415 cultivar was also identified, coinciding with the previous harvest.

For the 2015/16 crop, the averages ranged from $1853.33 \mathrm{~kg} \mathrm{ha}^{-1}$ to UFUS $1117-02$, to 3628.53 $\mathrm{kg} \mathrm{ha}^{-1}$ to TMG 801 (Table 2). Three genotypes of the program were highlighted: UFUS: 1117-05, 1117-07 and 1117-10, which obtained productivity above the national average, which was $2870 \mathrm{~kg} \mathrm{ha}^{-1}$ (CONAB, 2017). When comparing the first and third harvests, we can see that UFUS 1117-05, 
remained one of the most productive.

Table 2. Soybean productivity, in $\mathrm{kg} \mathrm{ha}^{-1}$ in the four seasons evaluated, in 14 soybean genotypes, in Uberlândia-MG.

\begin{tabular}{cccccc}
\hline Genotypes & $2013 / 14$ & $2014 / 15$ & $2015 / 16$ & $2016 / 17$ & Average \\
\hline UFUS 1117-01 & $2733.07 \mathrm{Ab}$ & $1908.01 \mathrm{Aa}$ & $2694.13 \mathrm{Ab}$ & $2283.12 \mathrm{Aa}$ & 2404.58 \\
TMG 801 & $3645.60 \mathrm{Aa}$ & $1972.72 \mathrm{Aa}$ & $3628.53 \mathrm{Aa}$ & $2805.11 \mathrm{Ba}$ & 3012.99 \\
UFUS 1117-02 & $1820.00 \mathrm{Ab}$ & $1224.57 \mathrm{Ab}$ & $1853.33 \mathrm{Ab}$ & $1638.52 \mathrm{Ab}$ & 1634.11 \\
BRSGO 7560 & $3238.40 \mathrm{Aa}$ & $2020.31 \mathrm{Ba}$ & $3238.40 \mathrm{Aa}$ & $3468.56 \mathrm{Aa}$ & 2991.42 \\
UFUS RIQUEZA & $2692.27 \mathrm{Ab}$ & $1126.42 \mathrm{Bb}$ & $2487.20 \mathrm{Ab}$ & $2200.95 \mathrm{Aa}$ & 2126.71 \\
UFUS 1117-03 & $2561.87 \mathrm{Ab}$ & $1806.23 \mathrm{Ba}$ & $2561.87 \mathrm{Ab}$ & $1392.39 \mathrm{Bb}$ & 2080.59 \\
UFUS 7415 & $3480.00 \mathrm{Aa}$ & $1748.28 \mathrm{Ba}$ & $2076.80 \mathrm{Bb}$ & $2385.66 \mathrm{Ba}$ & 2422.69 \\
UFUS 1117-05 & $2972.53 \mathrm{Aa}$ & $1436.11 \mathrm{Bb}$ & $2942.67 \mathrm{Aa}$ & $1378.72 \mathrm{Bb}$ & 2182.51 \\
UFUS 1117-06 & $2425.07 \mathrm{Ab}$ & $1278.82 \mathrm{Bb}$ & $2144.27 \mathrm{Ab}$ & $2656.74 \mathrm{Aa}$ & 2126.22 \\
UFUS 1117-07 & $2932.27 \mathrm{Aa}$ & $1328.43 \mathrm{Bb}$ & $2932.27 \mathrm{Aa}$ & $2368.32 \mathrm{Aa}$ & 2390.32 \\
UFUS 1117-08 & $2558.40 \mathrm{Ab}$ & $2088.94 \mathrm{Aa}$ & $2558.40 \mathrm{Ab}$ & $2523.92 \mathrm{Aa}$ & 2432.42 \\
UFUS 1117-09 & $2052.27 \mathrm{Ab}$ & $2016.06 \mathrm{Aa}$ & $2228.80 \mathrm{Ab}$ & $2599.65 \mathrm{Aa}$ & 2224.19 \\
UFUS 1117-10 & $2662.93 \mathrm{Ab}$ & $1077.04 \mathrm{Bb}$ & $2881.07 \mathrm{Aa}$ & $2283.12 \mathrm{Bb}$ & 2021.06 \\
UFUS 1117-11 & $2677.33 \mathrm{Ab}$ & $1616.60 \mathrm{Ba}$ & $2377.33 \mathrm{Ab}$ & $1040.67 \mathrm{Bb}$ & 1927.98 \\
\hline Average & 2746.57 & 1617.75 & 2614.65 & 2157.54 &
\end{tabular}

Means followed by the same upper and lower case vertical letters belong to the same statistical group, by the Scott-Knott test, at $5 \%$ probability.

In the 2016/17 crop, the averages were within the range of $1378.72 \mathrm{~kg} \mathrm{ha}^{-1}$ for UFUS 1117 05, at $3468.56 \mathrm{~kg} \mathrm{ha}^{-1}$ for BRSGO 7560 (Table 2). Only BRSGO 7560 cultivar had grain yield higher than the national average of the respective crop, $3362 \mathrm{~kg} \mathrm{ha}^{-1}$ (CONAB, 2017).

It was possible to observe that the 2014/15 season was the environment with the highest number of genotypes with low productivity, except for UFUS 1117-01, TMG 801, UFUS 1117-02, UFUS 1117-08 and UFUS 1117-09 (Table 2). In addition, UFUS 1117-01, UFUS 1117-02, UFUS 1117-08 and UFUS 1117-09 had high yields in all seasons (Table 2).

Due to the complex classification of $\mathrm{G} \times \mathrm{E}$ interaction, the identification of superior genotypes is difficult, and for this reason, the analysis of adaptability and phenotypic stability are justified in order to attenuate the effects of the interaction on the recommendation of cultivars (CRUZ; CARNEIRO; REGAZZI, 2014).

The Eberhart and Russel (1966) methodology, which is one of the most used methods to study the adaptability and stability in soybean, is based on a linear regression obtained between the productivity variable and the environmental index. A suitable interpretation is obtained when the regression coefficient $\left(R^{2}\right)$ is greater than 70\% (EBERHART; RUSSEL 1966; CAVALCANTE et al., 2014).

According to Table 3, it was possible to infer adequately all genotypes, with the exception of BRSGO 7560, UFUS 1117-03, UFUS 7415, UFUS
1117-11, UFUS 1117-06 and UFUS 1117-09, as they presented $\mathrm{R}^{2}$ varying from $0.01 \%$ to $60.49 \%$.

In the interpretation of the results two statistical hypotheses are elaborated: $\mathrm{H}_{0}: \beta_{i}=1 \mathrm{e}$ $\mathrm{H}_{1}: \beta_{i} \neq 1$, which informs about the adaptability, where $\beta_{l i}=1$ refers to genotypes with wide adaptability, $\beta_{l i}>1$ and $\beta_{i j}<1$ adaptability to favorable and unfavorable environments, respectively. The second hypothesis refers to stability: $\mathrm{H}_{0}: \hat{\sigma}_{d i}^{2}=0$ (high stability) and $\mathrm{H}_{1}: \hat{\sigma}_{d i}^{2} \neq 0$ (low stability). For Eberhart and Russel (1966) the ideal genotype is the one with high productivity, $\mathrm{R}^{2}$ equal to unity, $\hat{\sigma}_{d i}^{2}$ and $\beta_{i}$ non-significant. For this aspect, the ideal genotypes were TMG 801, UFUS 1117-01, UFUS 1117-07 and UFUS 1117-08 (Table 3 ), as they presented above-average productivity, $2284.13 \mathrm{~kg} \mathrm{ha}^{-1}$ (Table 4), were able to respond satisfactorily to the improvement of the environment and presented high productive capacity in favorable and unfavorable environments (CARVALHO et al., 2013).

In spite of the cultivar, UFUS Riqueza and the line UFUS 1117-02 were characterized as broad adaptation and high stability, they did not present high yields (Table 3). This information corroborates that obtained by Marques et al. (2010), who also identified the cultivar UFUS Riqueza, by the same method, as being of wide adaptation and high stability. However, the genotypes UFUS 7415, UFUS 1117-5, UFUS 1117-06 and UFUS 1117-11 were identified as having broad adaptation but low stability, while UFUS 1117-09 genotypes were 
adapted to unfavorable environments and high stability (Table 3).

Table 3. Soybean grain yield and parameters of adaptability and stability by the methods of Eberhart and Russel (1966) and Wricke (1965), in 14 soybean genotypes grown in 4 seasons, in Uberlândia-MG.

\begin{tabular}{|c|c|c|c|c|c|}
\hline \multirow{2}{*}{ Genotypes } & \multirow{2}{*}{$\begin{array}{l}\text { Productivity } \\
\mathrm{kg} \mathrm{ha}^{-1}\end{array}$} & \multicolumn{3}{|c|}{ Eberhart e Russel (1966) } & \multirow{2}{*}{$\begin{array}{c}\text { Wricke (1965) } \\
\omega_{i} \%\end{array}$} \\
\hline & & $\beta 1$ & $\sigma_{d i}^{2}$ & $\mathrm{R}^{2}$ & \\
\hline UFUS 1117-01 & 2404.58 & $0.76^{\mathrm{ns}}$ & $-77282.52^{\mathrm{ns}}$ & 99.40 & 0.73 \\
\hline TMG 801 & 3012.99 & $1.55^{\mathrm{ns}}$ & $-69682.66^{\mathrm{ns}}$ & 99.06 & 3.84 \\
\hline UFUS $1117-02$ & 1634.11 & $0.55^{\mathrm{ns}}$ & $-71937.75^{\mathrm{ns}}$ & 94.64 & 2.57 \\
\hline BRSGO 7560 & 2991.42 & $0.99^{\mathrm{ns}}$ & $176728.89^{*}$ & 60.49 & 7.64 \\
\hline UFUS RIQUEZA & 2126.71 & $1.33^{\mathrm{ns}}$ & $-38376.12^{\mathrm{ns}}$ & 94.47 & 2.44 \\
\hline UFUS 1117-03 & 2080.59 & $0.83^{\mathrm{ns}}$ & $156378.54^{\mathrm{ns}}$ & 53.56 & 7.36 \\
\hline UFUS 7415 & 2422.69 & $1.06^{\mathrm{ns}}$ & $329768.54^{* *}$ & 51.77 & 12.26 \\
\hline UFUS $1117-05$ & 2182.51 & $1.55^{\mathrm{ns}}$ & $180357.48^{*}$ & 78.46 & 11.32 \\
\hline UFUS 1117-06 & 2126.22 & $0.82^{\mathrm{ns}}$ & $203054.93^{*}$ & 48.27 & 8.81 \\
\hline UFUS $1117-07$ & 2390.32 & $1.46^{\mathrm{ns}}$ & $-50803.11^{\mathrm{ns}}$ & 96.75 & 3.26 \\
\hline UFUS 1117-08 & 2432.42 & $0.41^{\mathrm{ns}}$ & $-63838.15^{\mathrm{ns}}$ & 81.26 & 4.59 \\
\hline UFUS 1117-09 & 2224.19 & $0.02^{++}$ & $28172.43^{\mathrm{ns}}$ & 0.10 & 14.53 \\
\hline UFUS $1117-10$ & 2021.06 & $1.64^{+}$ & $51097.09^{\mathrm{ns}}$ & 88.98 & 8.62 \\
\hline UFUS 1117-11 & 1927.98 & $1.04^{\mathrm{ns}}$ & $321286.37^{* *}$ & 51.46 & 11.99 \\
\hline
\end{tabular}

$\omega_{i} \%$ : Wricke (1965) stability parameter; $\beta 1$ : adaptability parameter, $\hat{\sigma}_{\sigma i}^{2}$ : stability parameter and $\mathrm{R}^{2}$ coefficient of determination of Eberhart and Russel (1966); ns: not significant, * and ** significant at 5\% and $1 \%$ respectively by the $\mathrm{F}$ test; ${ }^{+}$and ${ }^{++}$significant at $5 \%$ and $1 \%$ respectively by the T-test.

The UFUS 1117-10 line was identified as being adaptable to favorable environmental conditions and high stability (Table 3 ). In studies with 29 soybean genotypes in the state of Mato Grosso, three lines of adaptation to favorable environments were identified, however, only one had high stability (BARROS et al., 2010).

Still, in Table 3, the methodology of Wricke (1965), based on the analysis of variance, uses the parameter of ecovalence to infer about the stability characteristics. Therefore, the genotype more stable is that with $\omega_{i}$ lowest value, indicating a lower contribution to the $\mathrm{G} \times \mathrm{E}$ interaction, in this way they were: UFUS 1117-01, TMG 801, UFUS 111702, UFUS Riqueza and UFUS 1117-07, being UFUS 1117-01 the most stable genotype, since its parameter $\omega_{i}$ was less than unity.

Of the genotypes analyzed, $57 \%$ had high $\omega_{i}$ values, being the genotype UFUS 1117-09 the largest contribution, with a value of $\omega_{i}=14,53 \%$ followed by UFUS 7415 , with $\omega_{i}=12.26 \%$. The Wricke methodology should be associated with Lin and Binns in order to increase safety in the recommendation of cultivars with high grain yield and that are stable (FRANCESHCI et al., 2010).

The Lin and Binns (1988) modified by Carneiro (1998) analysis provide information about the adaptability and stability of the genotype by the $\mathrm{Pi}$ parameter. The general recommendation is based on the original $\mathrm{Pi}$ of Lin and Binns, so, according to Table 4, the three genotypes that presented lower values of $\mathrm{Pi}$, and therefore greater stability were: BRSGO 7560, TMG 801, UFUS 1117-07.

The modification by Carneiro (1998) better stratified the genotypes for favorable and unfavorable conditions. Oliveira et al. (2006) recommend the use of the method of Lin and Binns modified by Carneiro. The UFUS 1117-05 line was adapted to favorable conditions, while UFUS 111709 for unfavorable conditions (Table 4), which was also identified by the Eberhart and Russel methodology (Table 3) as being adaptable to unfavorable conditions. The genotypes UFUS 111709 and UFUS 1117-02 presented the highest favorable Pi.

Silva and Duarte (2006), working with soybean, stated that the method of Lin and Binns modified by Carneiro should be used in combination with that of Eberhart and Russel. However, other authors believe that the method of Lin and Bins modified by Carneiro discriminates cultivars better than Wricke and Eberhart and Russel (FRANCESHCI et al., 2010).

Silva et al. (2008), analyzing methodologies of adaptability and stability, based on regression analysis, analysis of variance and non-parametric analysis, concluded that the best methodologies were those based on Lin and Binns modified by Carneiro and Annicchiarico (1992) that encompass a 
single adaptation and stability, facilitating the interpretation of the results.

Table 4. Soybean grain yield and parameters of adaptability and stability by Lin and Binns (1988) modified by Carneiro (1998) method in 14 soybean genotypes grown in 4 seasons, in Uberlândia-MG.

\begin{tabular}{|c|c|c|c|c|}
\hline Genotype & $\begin{array}{l}\text { Productivity } \\
\mathrm{kg} \mathrm{ha}^{-1}\end{array}$ & General Pi & Pi favorable & Unfavorable Pi \\
\hline UFUS 1117-01 & 2404.58 & 392976.34 & 426455.11 & 359497.57 \\
\hline TMG 801 & 3012.99 & 56709.22 & 0.00 & 113418.44 \\
\hline UFUS 1117-02 & 1634.11 & 1322539.21 & 1621037.60 & 1024040.82 \\
\hline BRSGO 7560 & 2991.42 & 40340.80 & 79503.96 & 1177.63 \\
\hline UFUS RIQUEZA & 2126.71 & 593094.70 & 552871.55 & 633317.85 \\
\hline UFUS 1117-03 & 2080.59 & 837833.05 & 578063.93 & 1097602.17 \\
\hline UFUS 7415 & 2422.69 & 465502.05 & 608824.92 & 322179.17 \\
\hline UFUS 1117-05 & 2182.51 & 714631.26 & 230857.95 & 1198404.56 \\
\hline UFUS $1117-06$ & 2126.22 & 626011.23 & 923187.29 & 328835.18 \\
\hline UFUS 1117-07 & 2390.32 & 347816.62 & 248407.93 & 447225.31 \\
\hline UFUS 1117-08 & 2432.42 & 402440.95 & 581797.30 & 223084.61 \\
\hline UFUS 1117-09 & 2224.19 & 657285.08 & 1124491.13 & 190079.02 \\
\hline UFUS $1117-10$ & 2021.06 & 821223.85 & 381085.05 & 1261362.64 \\
\hline UFUS $1117-11$ & 1927.98 & 1077597.96 & 625760.44 & 1529435.47 \\
\hline
\end{tabular}

The evaluation of the $\mathrm{G} \times \mathrm{E}$ interaction, through the analysis of additive main effects and multiplicative interactions (AMMI), has been successfully applied to several crops (MELO et al., 2007; MARJANOVIĆ JÉROMELA et al. 2011). It has the advantage of discarding the portion of the interaction noise, which is neither attributed to the genotype not to the environment, which improves the predictive capacity of the model, bringing direct benefits to the selection of genotypes (ZOBEL et al., 1988).

By the AMMI method, the sum of squares of the interaction was decomposed into three main component axes, and it was observed that the first two main components in the AMMI analysis explained $84.96 \%$ of the $\mathrm{G} \times \mathrm{E}$ interaction, a value above the limit of $70 \%$, which is suggested to have a good fit of the model and greater accuracy in the predictions (RAMALHO et al., 2012).

For the interpretation of stability by the AMMI 2 (Figure 1), the distance from the representative points of the genotypes and the environment to the zero score of the two main components should be observed (DUARTE; VENCOVSKY, 1999). Thus, the genotypes UFUS 1117-01, UFUS 7415 and UFUS 1117-05 presented greater stability, whereas BRSGO 7560, UFUS 1117-04, UFUS 1117-08 and UFUS 1117-05 smaller, that is, they contributed the most for the $G$ $\mathrm{x} E$ interaction (Figure 1)

Gonçalves, Mauro and Cargnelutti Filho (2007), studying 29 soybean genotypes for adaptability and stability for grain yield at different sowing times, concluded that the most unstable genotypes were the most productive, however, one of the main objectives of breeding is to select productive genotypes associated with high stability. In this context, all genotypes identified as stable had above-average productivity.

Environments 1 and 3 were classified as favorable, while 2 and 4 unfavorable, thus, the most adapted genotypes for environments 1 and 3 were: TMG 801, UFUS 1117-05, UFUS 1117-07 and UFUS 1117-10; for the environment 2 were: UFUS 1117-01, UFUS 1117-02, UFUS 1117-08, UFUS 1117-09 and for environment 4: BRSGO 7560, UFUS Riqueza, UFUS 7415, UFUS 1117-06, but UFUS 1117-03 and UFUS 1117-11 genotypes were not adaptable to any of the environments tested (Figure 1).

The analysis of adaptability and stability by the Centroid method is distinguished by considering genotypes of maximum specific adaptation as those genotypes with maximum values for certain groups of environments (favorable or unfavorable) and minimum for another group, and not one that shows good performance in the groups of favorable or unfavorable environments (ROCHA et al., 2005).

Predicting the graphical dispersion analysis of the genotypes, the eigenvalues were obtained through the methodology of the main components, in which the first two main components explained $88.13 \%$ of the total variation. 


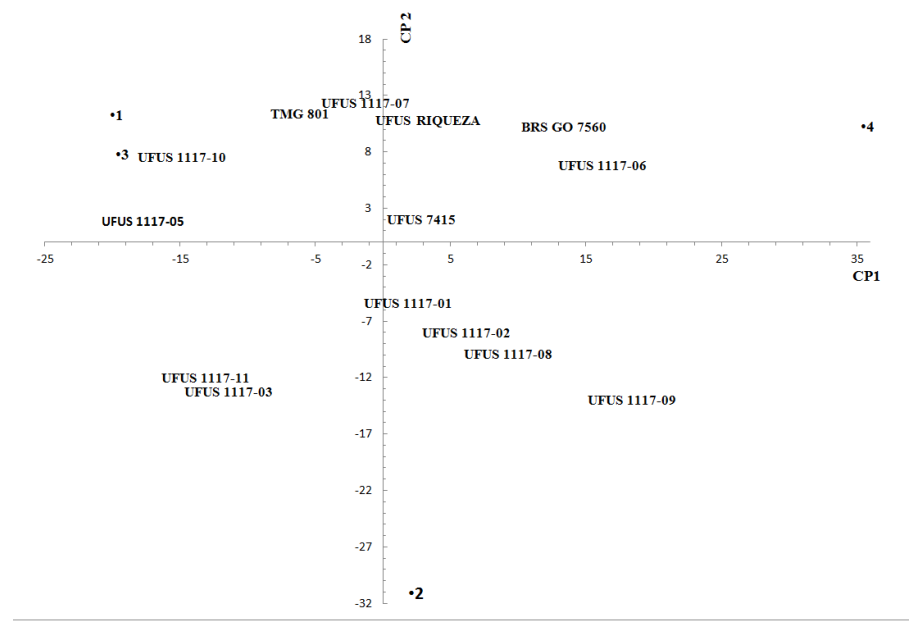

Figure 1. Plotting the scores of the first two main components, according to the AMMI 2 model for grain yield in $\mathrm{kg} \mathrm{ha}^{-1}$, for 14 soybean genotypes grown in four environments, in Uberlândia - MG. CP1: 58.93\% and CP2: $84.97 \%$.

As two eigenvalues seemed to be sufficient, the evaluation of the position of the genotypes can be done through two-dimensional graphs (CARVALHO et al., 2002). In Figure 3 it was possible to observe the plot of the genotypes according to the Centroid, which allowed verifying the behavior of the genotypes in relation to the ideologies recommended by the method.
The arrow format that assumes the link between the points representing the ideotypes allows a quantitative interpretation of the adaptability of the genotypes. As the genotypes move away from the tail to the arrowhead, productivity increases gradually (HAMAWAKI, 2014).

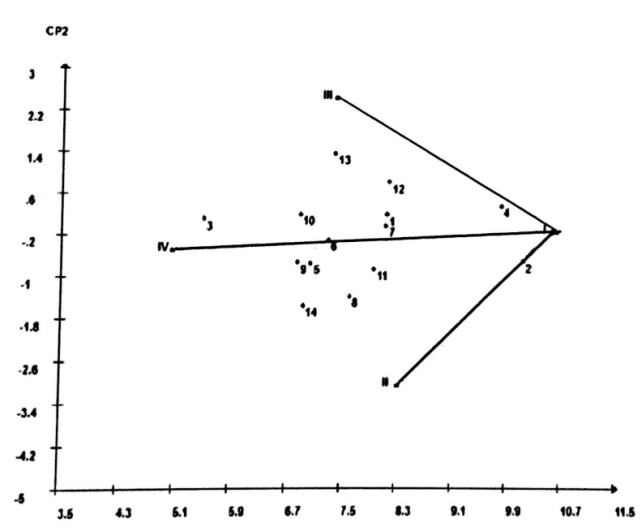

Figure 2. Graphical dispersion of the first two main components of the 14 soybean genotypes, for grain yield, $\mathrm{kg} \mathrm{ha}^{-1}$, in four environments. The four points numbered with Roman numerals represent the ideotypes, where: I, maximum general adaptability; II, maximum specific adaptability to favorable environments; III, maximum specific adaptability to unfavorable environments; IV, minimum adaptability. (1) UFUS 1117-01; (2) TMG 801; (3) UFUS 1117-02; (4) BRS GO 7560; (5) UFUS RIQUEZA; (6) UFUS 1117-03; (7) UFUS 7415; (8) UFUS 1117-05; (9) UFUS 1117-11; (10) UFUS 1117-06; (11) UFUS 1117-07; (12) UFUS 1117-08; (13) UFUS 1117-09; (14) UFUS 1117-10.

A similar interpretation can be made, those genotypes positioned above the axis of the arrow are more apt to favorable environments and those below are apt to unfavorable environments. The distribution of the genotypes is heterogeneous, due mainly to the study character, grain yield, and allows associating the genotypes with most of the ideotypes (HAMAWAKI, 2014). 
Therefore, in interpreting Figure 2, the genotypes BRSGO 7560, TMG 801, UFUS 7415, UFUS 1117-01, UFUS 1117-08 and UFUS 1117-07 were the most productive, and $57 \%$ of the genotypes were located above the central axis of the arrow, characterizing adaptation to favorable environments. In Table 5, there are the classifications of the genotypes in relation to the Centroid method.

Table 5. Stability and adaptability parameters by the Centroid method (ROCHA et al., 2005), in 14 soybean genotypes grown in 4 crops, in Uberlândia-MG.

\begin{tabular}{cc}
\hline Genotypes & Ranking \\
\hline TMG 801, BRSGO 7560, UFUS 7415, UFUS 1117-07 & I \\
UFUS 1117-05, UFUS 1117-10 & II \\
UFUS 1117-01, UFUS 1117-06, UFUS 1117-08, UFUS 1117-09 & III \\
UFUS 1117-02, UFUS RIQUEZA, UFUS 1117-03, UFUS 1117-11 & IV
\end{tabular}

I: general high adaptability, II: specific adaptability to favorable environments, III: specific adaptability to unfavorable environments, IV: poorly adapted.

The genotypes TMG 801, BRSGO 7560, UFUS 7415 and UFUS $1117-07$ were classified as high general adaptability (Table 5), which means less contributed to $\mathrm{G} \times \mathrm{E}$ interaction, and express the concept of stability proposed by Cruz, Regazzi and Carneiro (2004), therefore, they are considered more stable (VASCONCELOS et al., 2011).

Two genotypes were classified as specific adaptability to favorable environments: UFUS 1117-05 and UFUS 1117-10; four genotypes of specific adaptability to unfavorable environments: UFUS 1117-01, UFUS 1117-06, UFUS 1117-08 and UFUS 1117-09 and, finally, four low adaptation genotypes: UFUS 1117-02, UFUS Riqueza, UFUS 1117-03 and UFUS 1117-11 (Table 5).

\section{CONCLUSIONS}

The UFUS 1117-01 lineage was identified by the methodologies of Eberhart and Russel, Wricke, AMMI 2 and Centroid as a genotype of high productive stability.
The UFUS 1117-07 strain showed high stability by the methods Eberhart and Russel, Wricke, Lin and Binns modified by Carneiro and wide adaptability by Eberhart and Russel and Centroid.

As for the UFUS 1117-09 lineage, it was identified as adaptive to unfavorable environments by the methods of Lin and Binns modified by Carneiro and Centroid.

The UFUS 1117-10 genotype presented favorable environmental adaptability by Centroid method and its characterization was complemented by Eberhart and Russel, which identified the genotype as having high stability.

The methods Eberhart and Russel and Centroid have reaffirmed among themselves the information contemplated in their analyzes, showing that they can be used to increase certainty regarding the classification of soybean genotypes.

RESUMO: O melhoramento genético da soja visa à obtenção de genótipos produtivos, então é necessário que os componentes genéticos, ambientais e a interação entre eles sejam compreendidos. A interação G x A é o comportamento diferencial dos genótipos frente às variações ambientais. O objetivo foi estudar a interação $G \times A$ e analisar a adaptabilidade e estabilidade produtiva de genótipos de soja sob infecção natural por ferrugem, sem fungicida. $O$ experimento foi conduzido no Programa de Melhoramento Genético da UFU. Quatorze genótipos de soja foram avaliados, sendo 10 linhagens desenvolvidas pelo Programa de Melhoramento Genético de Soja da UFU (UFUS 1117-01, UFUS 1117-02, UFUS 1117-03, UFUS 1117-05, UFUS 1117-06, UFUS 1117-07, UFUS 1117-08, UFUS 1117-09, UFUS 111710 e UFUS 1117-11) e 4 cultivares ( UFUS 7415, UFUS Riqueza, TMG 801 e BRSGO 7560), em quatro safras: 2013/14, 2014/15, 2015/16 e 2016/17, em delineamento de blocos casualizados. A interação G x A foi significativa e complexa e o $\mathrm{H}^{2}$ foi de $85,97 \%$ indicando superioridade da variação genética em relação a ambiental. A média de produtividade de grãos foi $2284,13 \mathrm{~kg} \mathrm{ha}^{-1}$. O genótipo UFUS 1117-01 foi identificado pelas metodologias de Eberhart e Russel, Wricke, AMMI 2 e Centroide como sendo um genótipo de alta estabilidade produtiva. A linhagem UFUS 1117-07 apresentou alta estabilidade por Eberhart e Russel, Wricke, Lin e Bins modificado por Carneiro e ampla adaptabilidade por Eberhart e Russel e Centroide. O genótipo UFUS 1117-09 foi identificado como sendo adaptável a ambientes desfavoráveis por Lin e Bins modificado por Carneiros e Centroide, e UFUS 1117-10 apresentou adaptabilidade a ambiente favoráveis pelo método Centroide e alta estabilidade por Eberhart e Russel. 
PALAVRAS-CHAVE: Glycine max. Interação G x A. Recomendação de cultivares. Análises biométricas.

\section{REFERENCES}

ANNICCHIARICO, P. Cultivar adaptation and recomendation from alfafa trials in Northern Italy. Journal of Genetics and Breeding, Itália, v. 46, n. 1, p. 269-278, 1992.

BARROS, H. B. SEDIYAMA, T.; TEIXEIRA, R. C.; FIDELIS, R. R.; CRUZ, C. D.; REIS, M.S. Adaptabilidade e estabilidade de genótipos de soja avaliados no estado do Mato Grosso. Revista Ceres, Viçosa, v. 57, n. 3, p. 359-366, 2010 .

BATISTA, R. O.; HAMAWAKI, R. L.; SOUSA, L. B.; NOGUEIRA, A. P. O.; HAMAWAKI, O. T. Adaptability and stability of soybean genotypes in off-season cultivation. Genetics and Molecular Research, Ribeirão Preto, v. 14, n. 3, p. 9634-9645, 2015. https://doi.org/10.4238/2015.August.14.26

BORÉM, A.; MIRANDA, G. V. Interação genótipo x ambiente. In: BORÉM, A.; MIRANDA, G. V. Melhoramento de Plantas. 6. ed. Viçosa: Editora UFV, 2013, p. 131-144.

CARNEIRO, P. C. S. Novas metodologias de análise da estabilidade e adaptabilidade de comportamento. $1998.168 \mathrm{f}$. Tese (Doutorado) - Universidade Federal de Viçosa, Viçosa, 1998.

CARVALHO, E. V.; PELUZIO, J. M.; SANTOS, W. F.; AFFERRI, F. S.; DOTTO, M. A; Adaptabilidade e estabilidade de genótipos de soja em Tocantins. Revista Agroambiente Online, Roraima, v. 7, n. 2, p. 162-169, 2013.

https://doi.org/10.18227/1982-8470ragro.v7i2.1235

CARVAlHO, H. W. L. SILVA, M. L.; CARDOSO, M. J.; SANTOS, M. X, TABOSA, J. N., CARVALHO, C. L.; LIRA. M. A. Adaptabilidade e estabilidade de cultivares de milho no Nordeste brasileiro no triênio de 1998 a 2000 . Pesquisa Agropecuária Brasileira, Brasília, v. 37, p. 1581-1588, 2002. https://doi.org/10.1590/S0100-204X2002001100009

CAVALCANTE, A. K. HAMAWAKI, O. T.; HAMAWAKI, R. L.; SOUSA, L. B.; NOGUEIRA, A. P. O.; HAMAWAKI, C. D. L. Adaptabilidade e Estabilidade Fenotipica de Genótipos de Soja em Porto Alegre do Norte, Mt. Bioscience Journal, Uberlândia, v. 30, n. 4, p. 942-949, 2014.

COCKERHAM, C. C. Estimation of genetic variances. In: HANSON, W. D.; ROBINSON, H. F. (Ed.). Statistical genetics and plant breeding. National Academy of Sciences, Washington, 1963, p. 53-93.

CONAB. Acompanhamento da safra brasileira: grãos - safra 2016/17 - décimo segundo levantamento. Companhia Nacional de Abastecimento, v. 4, n. 4, p. 1-158, 2017. ISSN: 23186852.

CRUZ, C. D. Genes Software extended and integrated with the R, Matlab and Selegen. Acta Scientiarum. Agronomy, Maringá, v. 38, n. 4, p. 547-552, 2016.

CRUZ, C. D.; CARNEIRO, P. C. S.; REGAZZI, A. J. Modelos biométricos aplicados ao melhoramento genético. Viçosa: Imprensa Universitária, v. 2, 2014, 668p.

CRUZ, C. D.; CASTOLDI, F. L. Decomposição da interação genótipo x ambiente em parte simples e complexa. Revista Ceres, Viçosa, v. 38, n. 219, p. 422-430, 1991.

CRUZ, C. D.; REGAZZI, A. J.; CARNEIRO, P. C. S. Modelos biométricos aplicados ao melhoramento genético. 3.ed. Viçosa: UFV, v. 1. 2004, 480p.

DUARTE, J. B.; VENCOVSKY, R. Interação genótipo x ambientes: uma introdução à análise AMMI. Ribeirão Preto: Sociedade Brasileira de Genética, 1999. 60p. (Série monográfica, 9).

EBERHART, S. A.; RUSSEL, W. A. Stability parameters for comparing varieties. Crop Science, Madison, v. 1, n. 05, p. 36-40, 1966. https://doi.org/10.2135/cropsci1966.0011183X000600010011x 
FINLAY, K, W; WILKINSON, G. N. The analysis of adaptation in a plantbreeding programe. Australian Journal of Agricultural Research, Australia, v. 14, n. 5, p. 742-754, 1963. https://doi.org/10.1071/AR9630742

FRANCESCHI, L. BENIN, G.; MARCHIORO, V. S.; MARTIN, T. N., SILVA, R. R.; SILVA, C. L. Métodos para análise de adaptabilidade e estabilidade em cultivares de trigo no estado do Paraná. Bragantia, Campinas, v. 69 , n. 4, 2010.

GARBUGLIO, D. D.; FERREIRA, D. F. FGGE method: description and application in data from maize cultivars. Euphytica, Netherlands, v. 204, p. 723-737, 2015. https://doi.org/10.1007/s10681-015-1375-6

GONÇALVES, E. C. P.; MAURO, A. O.; CARGNELUTTI-FILHO, A. Adaptabilidade e estabilidade de genótipos de soja conduzidos em duas épocas de semeadura, na região de Jaboticabal- SP. Revista Científica. Jaboticabal, v. 35, n. 1, p. 61-70, 2007.

HAMAWAKI, R. L. Adaptabilidade e estabilidade fenotípica de genótipos de soja pelos métodos de Toler e Centróide. 2014. 55p. Tese (Doutorado)- Universidade Federal de Uberlândia - UFU, Uberlândia, 2014.

HENDERSON, C. R. 1984. Aplications of linear models in animal breeding. University of Guelph, Guelph. 462 p.

LEITE, W. S.; PAVAN, B. E.; FILHO, C. H. A. M.; FEITOSA, F. S.; OLIVEIRA, C. B. Estimativas de parâmetros genéticos e correlações entre caracteres agronômicos em genótipos de soja. Revista Nativa, Mato Grosso, v. 3, n. 4, p. 241-245, 2015. https://doi.org/10.14583/2318-7670.v03n04a03

LIN, C. S.; BINNS, M. R. A superiority measure of cultivar performance for cultivar x location data. Canadian Journal of Plant Science, Canadá, v. 68, p. 193-198, 1988. https://doi.org/10.4141/cjps88-018

MARJANOVIC- JEROMELA, A. NAGL, N.; GVOZDANOVIC- VARGA, J.; HRISTOV, N.; KONDIC-SPIKA, A.; VASIC, M.; MARINKOVIC, R. Genotype by environment interaction for seed yield per plant in rapeseed using AMMI model. Pesquisa Agropecuária Brasileira, Brasília, v. 46, n. 2, p. 174-181, 2011. https://doi.org/10.1590/S0100204X2011000200009

MARQUES, M. C. Adaptabilidade, estabilidade e diversidade genética de cultivares de soja em três épocas de semeadura, em Uberlândia-MG. 2010. 95p. Dissertação (Mestrado)- Universidade Federal de Viçosa- UFV, Viçosa, 2010.

MELO, L. C.; MELO, P. G. S.; FARIA, L. C.; DIAZ, J. L. C.; PELOSO, M. J.; RAVA, C. A.; COSTA, J. G. C. Interação com ambientes e estabilidade de genótipos de feijoeiro-comum na Região Centro-Sul do Brasil. Pesquisa Agropecuária Brasileira, Brasília, v. 42, p. 715-723, 2007. https://doi.org/10.1590/S0100-204X2007000500015

OLIVEIRA, A. B. ; DUARTE, J. B.; PINHEIRO, J. B. Emprego da análise AMMI na avaliação da estabilidade produtiva em soja. Pesquisa Agropecuária Brasileira, Brasília, v. 38, p. 357-364, 2003. https://doi.org/10.1590/S0100204X2003000300004

OLIVEIRA, E. J. GODOY, E. J.; MORAES, A. R. A.; MARTINS, A. L. M.; PEREIRA, J. C. V. N. A.; BORTOLETTO, N.; KASAI, F. S. Adaptabilidade e estabilidade de amendoim de porte rasteiro. Pesquisa Agropecuária Brasileira, Brasília, v. 41, p. 1253-1260, 2006. https://doi.org/10.1590/S0100-204X2006000800007

RAMALHO, M. A. P. ABREU, A. F.B.; SANTOS, J. B.; NUNES, J. A. R. Aplicações da Genética Quantitativa no Melhoramento de Plantas Autógamas. Lavras: Editora UFLA, 2012, 522p.

RESENDE, M. D. V.; DUARTE, J. B. Precisão e controle de qualidade em experimentos de avaliação de cultivares. Pesquisa Agropecuária Tropical, Goiânia, v. 37, p. 182-194, 2007.

ROCHA, R. B. MURO-ABAD, J. I.;ARAUJO, E. F.;CRUZ, C. D. Avaliação do método centroide para estudo de adaptabilidade ao ambiente de clones de Eucalyptus grandis. Ciência Florestal, Santa Maria, v. 15, n. 3, p. 255-266, 2005. https://doi.org/10.5902/198050981863 
ROMANATO, F. N.; HAMAWAKI, O. T.; SOUSA, L. B.; NOGUEIRA, A. P. O.; NETO, D. P. C.; BORGES, C. C. R.; HAMAWAKI, C. D. L.; HAMAWAKI, R. L. Análises paramétricas e não paramétricas para determinação da adaptabilidade e estabilidade de genótipos de soja em três épocas de semeadura. Bioscience Journal, Uberlândia, v. 32, n. 3, p. 574-580, 2016. https://doi.org/10.14393/BJ-v32n3a2016-26078

SEDIYAMA, T.; SILVA, F.; BORÉM, A. Soja: do plantio à colheita. Viçosa, MG: UFV, 2015, 333p.

SILVA FILHO, J. L.; MORELLO, C, L.; FARIAS, F. J. C.; LAMAS, F. M., PEDROSA, M. B.; RIBEIROS, J. L. Comparação de métodos para avaliar a adaptabilidade e estabilidade produtiva em algodoeiro. Pesquisa Agropecuária Brasileira, Brasília, v. 43, n. 3, 2008.

SILVA, F. L.; SOARES, P. C.; CARGNIN, A.; SOUZA, M. A.; SOARES, A. A.; CORNÉLIO, M. O. C.; REIS, M. S. Methods of adaptability and stability analysis in irrigated rice genotypes in Minas Gerais, Brazil. Crop Breeding and Applied Biotechnology, Viçosa, v. 8, p. 119-126, 2008.

SILVA, W. C. J.; DUARTE, J. B. Métodos estatísticos para estudo de adapta- bilidade e estabilidade fenotípica em soja. Pesquisa Agropecuária Brasileira, Brasília, v. 41, p. 23-30. 2006. https://doi.org/10.1590/S0100204X2006000100004

VASCONCELOS, E. S.; REIS, M. S.; CRUZ, C. D.; SEDIYAMA, T.; SCAPIM, C.A Integrated method for adaptability and phenotypic stability analysis. Acta Scientiarum Agronomy, Maringá, v. 33, n. 2, p. 251-257, 2011. https://doi.org/10.4025/actasciagron.v33i2.8272

VASCONCELOS, E. S.; REIS, M. S.; SEDIYAMA, T.; CRUZ, C. D. Estimativas de parâmetros genéticos da qualidade fisiológica de sementes de genótipos de soja produzidas em diferentes regiões de Minas Gerais. Semina: Ciências Agrárias, Londrina, v. 33, n. 1, p. 65-76, 2012.

WRICKE, G. Zur Berechnung der Ökovalenz bei Sommerweizen und Hafer. Zeitschrift für Pflanzenzüchtung, v. 52, p. 127-138, 1965.

YOKOMIZO, G. K.; VELLO, N. A. Coeficiente de determinação genotípica em topocruzamentos de soja tipo alimento com tipo grão. Pesquisa Agropecuária Brasileira, Brasília, v. 35, n. 11, p. 2223-2228, 2000.

https://doi.org/10.1590/S0100-204X2000001100016

https://doi.org/10.1590/S0100-204X2000001100014

ZOBEL, R. W.; WRIGHT, M. J.; GAUCH, H. G. Statistical analysis of a yield trial. Agronomy Journal, Estados Unidos, v. 80, p. $388-393,1988$. 